\title{
DETERMINATION OF STABILITY CONSTANTS OF IRON(III) AND CHROMIUM(III)-NITRILOTRIACETATE-METHYL CYSTEINE MIXED COMPLEXES BY ELECTROPHORETIC TECHNIQUE
}

\author{
Brij Bhushan Tewari* \\ Department of Chemistry, Faculty of Natural Sciences, University of Guyana, \\ Turkeyen Campus, P.O. Box 10 1110, Georgetown, Guyana (S. America)
}

(Received February 10, 2003)

\begin{abstract}
The stability constants of $\mathrm{Fe}(\mathrm{III})$ and $\mathrm{Cr}(\mathrm{III})$ with methyl cysteine and nitrilotriacetate (NTA) were determined by paper electrophoretic technique. Beside binary ternary complexes have also been studied, in which nitrilotriacetate and methyl cysteine acts as primary and secondary ligand, respectively. The stability constants of mixed ligand complexes metal (M)-nitrilotriacetate-methyl cysteine have been found to be $5.72 \pm 0.09$ and $5.54 \pm 0.11$ (log $\mathrm{K}$ values) for $\mathrm{Fe}(\mathrm{III})$ and $\mathrm{Cr}$ (III) complexes, respectively, at $35{ }^{\circ} \mathrm{C}$ and ionic strength $0.1 \mathrm{M}$.
\end{abstract}

KEY WORDS: Paper electrophoresis, Iron(III) complexes, Chromium(III) complexes, Mixed ligand metal complexes, Stability constants, Nitrilotriacetic acid, Methyl cysteine

\section{INTRODUCTION}

A significant development on the determination of stability constants of complexes was made by Jokl [1] in 1964. A theoretical treatment similar to that of Jokl was adopted by Biernat [2] for the study of step wise complex formation. Iron and chromium are essential and beneficial metals, respectively [3]. Iron is an important constituent of the blood and tissues of animal body. Most of the iron in the body present as heme proteins [4]. Chromium(III) is required as a part of the glucose tolerance factor (GTF), for the initiation of peripheral insulin action [5]. The immune system of the body provides protection against foreign substances and pathogenic organisms. The chromium ion is reported to mediate the immune response [6]. The significance of sulphur containing amino acid like methyl cysteine is enhanced by the fact that in recent years, it has been utilized in connection with rheumatoid arthritis [7]. The iron(III) and chromium(III) metal ions have significant biomedical applications but are toxic at higher concentration [8-25]. High concentration of iron in living systems can be prevented by the use of iron-specific chelating agents [26]. A study on the feasibility of controlling the level of iron(III) and chromium(III) metal ions by complexation seems to be very interesting.

The electrophoretic technique usually suffers from a number of defects. Temperature during electrophosis, capillary flow on the paper, electroosmosis, adsorption and molecular sizing affect the mobility of the charged moieties [27, 28]. The technique described here is almost free from these vitiating factors. The technique is very convenient in use. It gives results in fair agreement with the accepted literature values. The stability constants of metal complexes can be very easily calculated by this technique, so the present paper electrophoretic technique have significant advantages over other methods reported in chemical literature for the determination of stability constants of metal complexes.

Publications [29-32] from our laboratory described a new method for study of mixed complexes. A search of literature indicated that there is no report available on binary and mixed complexes of $\mathrm{Fe}(\mathrm{III})$ and $\mathrm{Cr}(\mathrm{III})$ with methyl cysteine and nitrilotriacetate. In view of this

*Corresponding author. Tel.: 592-222-6004. Fax: 592-222-3596. E-mail: brijtew@yahoo.com 
attemps were made to establish the optimum conditions for metal-methyl cysteine, metalnitrilotriacetate and metal-NTA-methyl cysteine complexes formation. In addition, this paper describes a paper electrophoretic method for the determination of the stability constants of these complexes.

\section{EXPERIMENTAL}

\section{Apparatus}

A Systronic (Naroda, India) Model 604 electrophoresis system was used. It has a built-in power supply (a.c.-d.c.) that is fed directly to a paper electrophoresis tank. In order to maintain the temperature constant, two hollow metallic plates coated with thin plastic paper on the outer surface were used for sandwiching paper strips and thermostated water $\left(35^{\circ} \mathrm{C}\right)$ was circulated through these plates. The $\mathrm{pH}$ measurements were made with an Elico (Hyderabad, India) Model $\mathrm{L}_{1-10} \mathrm{pH}$ meter using a glass and calomel electrodes assembly, working on $220 \mathrm{~V} / 50 \mathrm{~Hz}$ established a.c. mains.

\section{Chemicals}

Solutions of iron(III) and chromium(III) metal perchlorate were prepared by precipitation of metal carbonates from $0.1 \mathrm{M}$ solution of sulphates of $\mathrm{Fe}(\mathrm{III})$ and $\mathrm{Cr}$ (III) with the solution of sodium carbonate (chemically pure grade, BDH, Poole, UK). The precipitates were thoroughtly washed with water and treated with a calculated amount of AnalaR grade perchloric acid. These were boiled on a water bath and then filtered to get a stock solution of metal perchlorate $5.0 \mathrm{x}$ $10^{-3} \mathrm{M}$.

Metal spots were detected on the paper using potassium ferrocyanide solution (BDH, Poole, UK) for Fe(III) and 1-(2-pyridylazo)-2-naphthol (PAN) (E. Merck, Darmstadt, Germany) for $\mathrm{Cr}$ (III). A saturated aqueous solution $(0.9 \mathrm{~mL})$ of silver nitrate was diluted with acetone to 20 $\mathrm{mL}$. Glucose, as the black spot, was detected by spraying with this solution and then with $2 \%$ ethanolic sodium hydroxide.

\section{Background electrolyte}

The background electrolytes used in the study of binary complexes were $0.1 \mathrm{M}$ perchloric acid and $0.01 \mathrm{M}$ methyl cysteine. For the study of ternary system the background electrolytes used were $0.1 \mathrm{M}$ perchloric acid, $0.01 \mathrm{M}$ NTA and various amounts of $0.01 \mathrm{M}$ methyl cysteine. The ternary system was maintained at $\mathrm{pH} 8.5$ by the addition of sodium hydroxide. A $0.5 \mathrm{M}$ methyl cysteine solution was prepared from AnalaR grade chemicals (BDH, Poole, UK). A $0.01 \mathrm{M}$ NTA solution was prepared from the compound obtained from E. Merck (Darmstadt, Germany).

\section{Procedure}

The hollow base plate in the instrument was made horizontal with a spirit level. A $150-\mathrm{mL}$ volume of background electrolyte was placed in each tank of electrophoretic apparatus. Paper strips (Whatman No. 1) of the size $30 \mathrm{x} 1 \mathrm{~cm}^{2}$ in triplicate were then spotted with metal ion solutions and glucose in the centre with a micropipette and were subsequently placed on the base plate and sandwiched under the upper hollow metallic plate with the ends of strips lying in the two sides of the tank solution. A $200 \mathrm{~V}$ potential difference was then applied between the tank solutions and electrophoresis was carried out for $60 \mathrm{~min}$. Subsequently the strips were removed and the spots were detected. The average movement of metal ions spots on the triplicate strips were noted for calculations and the movement of the glucose spot was used as a 
correction factor. It was found that the variation in the movement was about $\pm 5 \%$. The mobilities were calculated by dividing the distance by the potential gradient and are expressed in $\mathrm{cm}^{2} \mathrm{~V}^{-1} \mathrm{~min}^{-1}$.

\section{RESULTS AND DISCUSSION}

\section{Metal(III)-methyl cysteine binary systems}

The ionophoretic mobility of metal spot against a $\mathrm{pH}$ gives a curve with the number of plateaus shown in Figure 1. Every plateau indicates the formation of certain complex species. A plateau is an indication of $\mathrm{pH}$ range, where speed is practically constant. In the region of first plateau metal ions are uncomplexed. Figure 1 reveals that second plateau lies in positive region indicating the cationic nature of 1:1 metal complex. With increase of $\mathrm{pH}$ mobility decreases giving rise to third plateau in positive region indicating formation of 1:2 metal complexes of cationic nature. Chemical literature also assigns prominent chelating properties of the unprotonated anionic species of methyl cysteine ruling out any such property to zwitterion [33]. Further increase in $\mathrm{pH}$ has no effect on the mobility of metal ions. In view of above observations, the complexation of metal ions with methyl cysteine anion [ $\left.\mathrm{L}^{-}\right]$may be represented as

$$
\begin{array}{lll}
\mathrm{M}^{3+}+\mathrm{L}^{-} & \stackrel{\mathrm{K}_{1}}{\leftrightarrows} & \mathrm{ML}^{2+} \\
& \stackrel{\mathrm{K}_{2}}{ } & \\
\mathrm{ML}^{2+}+\mathrm{L}^{-} & \stackrel{\leftrightarrows}{\leftrightarrows} & \mathrm{ML}_{2}^{+}
\end{array}
$$

where $\mathrm{M}^{3+}=\mathrm{Fe}^{3+}$ and $\mathrm{Cr}^{3+}$ metal ions; $\left[\mathrm{L}^{-}\right]=$ligand methyl cysteine anion; $\mathrm{K}_{1}, \mathrm{~K}_{2}=$ first and second stability constants, respectively; $\mathrm{ML}^{2+}, \mathrm{ML}_{2}^{+}=1: 1$ and $1: 2$ metal complexes, respectively.

The overall mobility $U$ of the uncomplexed and complexed metal ions spot moving under the influence of electric field is given by equation

$$
\mathrm{U}=\underset{\mathrm{n}}{\sum} \mathrm{u}_{\mathrm{n}} \mathrm{f}_{\mathrm{n}}
$$

On taking into consideration the different equilibria, equation (3) is transformed into following useful form

$\mathrm{U}=\frac{\mathrm{u}_{\mathrm{o}}+\mathrm{u}_{1} \mathrm{~K}_{1}\left[\mathrm{~L}^{-}\right]+\mathrm{u}_{2} \mathrm{~K}_{1} \mathrm{~K}_{2}\left[\mathrm{~L}^{-}\right]^{2}}{1+\mathrm{K}_{1}\left[\mathrm{~L}^{-}\right]+\mathrm{K}_{1} \mathrm{~K}_{2}\left[\mathrm{~L}^{-}\right]^{2}}$

where $\mathrm{u}_{\mathrm{o}}, \mathrm{u}_{1}$ and $\mathrm{u}_{2}$ are mobilities of uncomplexed metal ion, 1:1 metal complex and 1:2 metal complex, respectively. For calculating first stability constants $\mathrm{K}_{1}$, the region between first and second plateau is pertinent. The overall mobility $U$ will be equal to the arithmetic mean of mobility of uncomplexed metal ion, $\mathrm{u}_{\mathrm{o}}$ and that of first complex, $\mathrm{u}_{1}$ at a $\mathrm{pH}$ where $\mathrm{K}_{1}=1 /\left[\mathrm{L}^{-}\right]$.

First stability constant $\mathrm{K}_{1}$ can be calculated with the help of concentration of methyl cysteine anion and dissociation constants of methyl cysteine $\left(\mathrm{k}_{1}=10^{2.55}, \mathrm{k}_{2}=10^{8.55}\right)[34,35]$. The concentration of chelating amino acid (methyl cysteine) species $\left[\mathrm{L}^{-}\right]$is calculated with the help of the following equation

$$
\left[\mathrm{L}^{-}\right]=\frac{\left[\mathrm{L}_{\mathrm{T}}\right]}{1+[\mathrm{H}] / \mathrm{k}_{2}+[\mathrm{H}]^{2} / \mathrm{k}_{1} \mathrm{k}_{2}}
$$


where $\left[\mathrm{L}_{\mathrm{T}}\right]=$ total concentration of ligand (methyl cysteine).

The second stability constant $\mathrm{K}_{2}$ of second complex can be calculated by taking into consideration, the region between second and third plateau of mobility curve. Their calculated values are given in Table 1.

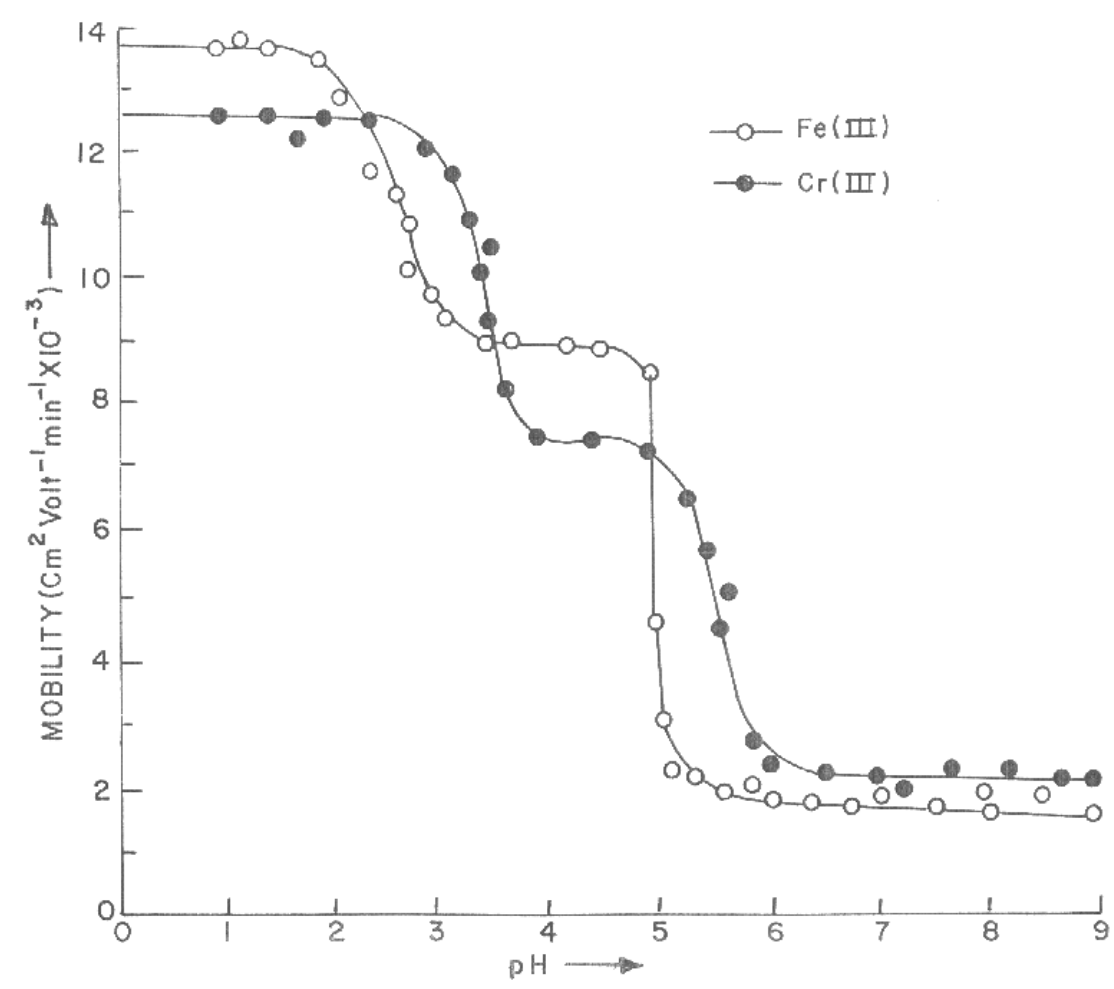

Figure 1. Mobility curves for the metal-methyl cysteine systems. Concentration of methyl cysteine $=1.0 \times 10^{-2} \mathrm{M}$. Concentration of $\mathrm{Fe}(\mathrm{IIII})$ and $\mathrm{Cr}(\mathrm{III})=5.0 \times 10^{-3} \mathrm{M}$. The paper strips were spotted with $0.1 \mu \mathrm{L}$ of sample solution and glucose (for making osmotic correction).

\section{Metal(III)-nitrilotriacetate binary systems}

Mobility curve of metal spots with nitrilotriacetate are shown in Figure 2. The mobility of last plateau in each case is in the zero region showing neutral nature of metal-nitrilotriacetate complexes. Hence, only one NTA anion is assumed to combined with one trivalent metal ion to give 1:1 M-NTA complex, which is in conformity with the findings of others $[36,37]$. The complexation of metal ion with nitrilotiracetate may be represented as:

$$
\mathrm{M}^{3+}+[\mathrm{NTA}]^{3-} \stackrel{\mathrm{K}_{3}}{\leftrightarrows} \quad[\mathrm{M}-\mathrm{NTA}]
$$

The stability constant $\mathrm{K}_{3}$ of binary complexes with NTA are calculated in the same manner as described for methyl cysteine. Their calculated values are given in Table 1.

Bull. Chem. Soc. Ethiop. 2004, 18(1) 
Table 1. Stability constants of binary and ternary complexes of $\mathrm{Fe}(\mathrm{III})$ and $\mathrm{Cr}$ (III). (Ionic strength $=0.1 \mathrm{M}$; temperature $=35{ }^{\circ} \mathrm{C} ; \quad \mathrm{NTA}$ anion $=\left[\mathrm{N}\left(\mathrm{CH}_{2} \mathrm{COO}\right)_{3}\right]^{3-} ;$ methyl cysteine anion = $\left.\left[\mathrm{H}_{2} \mathrm{C}\left(\mathrm{SCH}_{3}\right) \mathrm{CH}\left(\mathrm{NH}_{2}\right) \mathrm{COO}^{-}\right]\right)$.

\begin{tabular}{|c|c|c|c|c|}
\hline \multirow[t]{2}{*}{ Metal ions } & \multicolumn{4}{|c|}{ Stability constants $^{\mathrm{a}}$} \\
\hline & $\begin{array}{c}\mathrm{M} \\
\log \mathrm{K}_{1 \mathrm{ML}} \\
\end{array}$ & $\begin{array}{c}\mathrm{M} \\
\log \mathrm{K}_{2 \mathrm{ML} 2} \\
\end{array}$ & $\begin{array}{c}\mathrm{M} \\
\log \mathrm{K}_{3 \mathrm{M}-\mathrm{NTA}} \\
\end{array}$ & $\begin{array}{c}\text { M-NTA } \\
\log \mathrm{K}_{4} \text { M-NTA-L } \\
\end{array}$ \\
\hline $\mathrm{Fe}$ (III) & $8.37 \pm 0.04$ & $13.92 \pm 0.07$ & $11.57 \pm 0.03$ & $5.72 \pm 0.09$ \\
\hline $\mathrm{Cr}(\mathrm{III})$ & $7.09 \pm 0.06$ & $12.14 \pm 0.07$ & $10.60 \pm 0.09$ & $5.54 \pm 0.11$ \\
\hline
\end{tabular}

$\stackrel{\mathrm{a}}{\log \mathrm{K}_{1} \mathrm{ML}}=[\mathrm{ML}] /[\mathrm{M}][\mathrm{L}] ; \log \mathrm{K}_{2 \mathrm{ML} 2}^{\mathrm{M}}=\left[\mathrm{ML}_{2}\right] /[\mathrm{ML}][\mathrm{L}] ;$

$\mathrm{M}$

M-NTA

$\log \mathrm{K}_{3 \mathrm{M}-\mathrm{NTA}}=[\mathrm{M}-\mathrm{NTA}] /[\mathrm{M}][\mathrm{NTA}] ; \log \mathrm{K}_{4 \mathrm{M}-\mathrm{NTA}-\mathrm{L}}=[\mathrm{M}-\mathrm{NTA}-\mathrm{L}] /[\mathrm{M}-\mathrm{NTA}][\mathrm{L}]$;

$\mathrm{M}=$ metal cation; $\mathrm{L}=$ ligand (methyl cysteine); $\mathrm{NTA}=$ nitrilotriacetate .

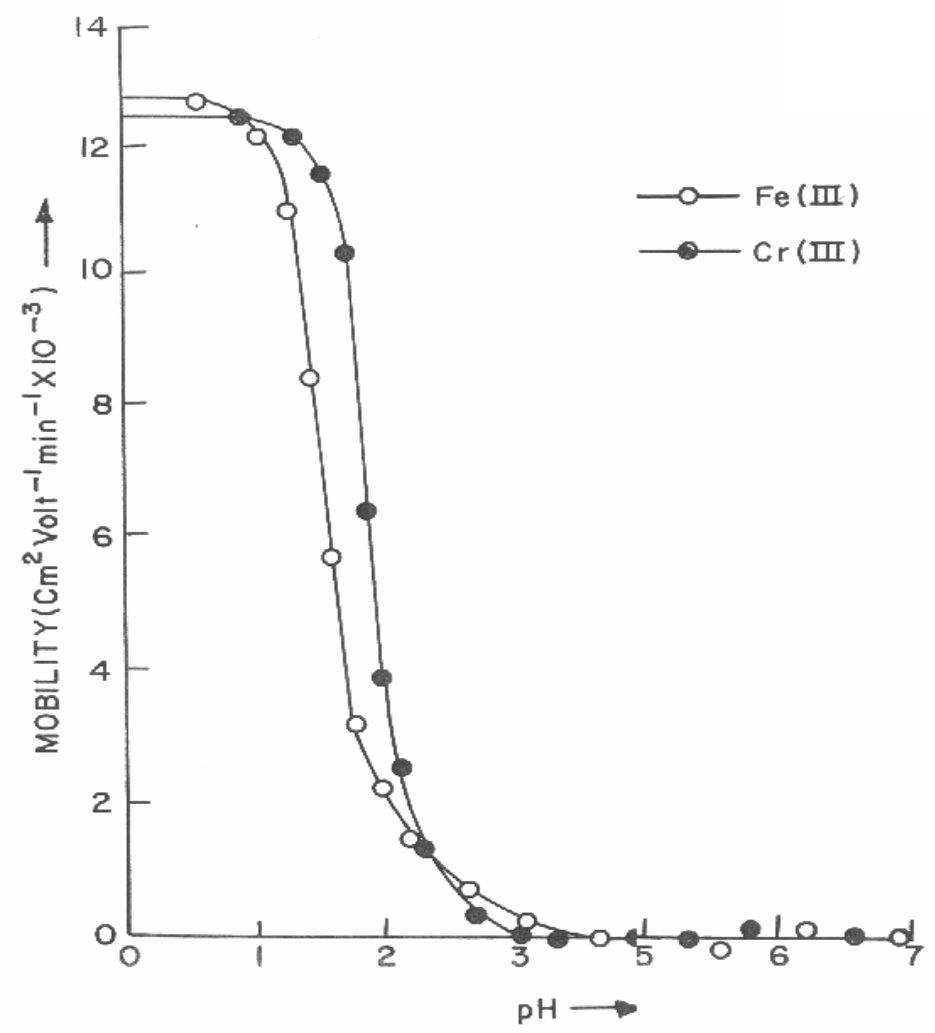

Figure 2. Mobility curves for the metal-NTA systems. Concentration of NTA $=1.0 \times 10^{-3} \mathrm{M}$. Concentration of $\mathrm{Fe}(\mathrm{III})$ and $\mathrm{Cr}(\mathrm{III})=5.0 \times 10^{-3} \mathrm{M}$. The paper strips were spotted with $0.1 \mu \mathrm{L}$ of sample solution and glucose (for making osmotic correction).

Bull. Chem. Soc. Ethiop. 2004, 18(1) 
Metal(III)-nitrilotriacetate-methyl cysteine mixed systems

The plot of mobility against log of concentration of added methyl cysteine gives a curve with two plateaus shown in Figure 3. It was observed from the study of metal-methyl cysteine and metal-nitrilotriacetate system that these complexes are formed at $\mathrm{pH}$ lower than 8.5. Thus it would be proper to study the transformation of metal-NTA binary complexes into metal-NTAmethyl cysteine mixed complexes at $\mathrm{pH} 8.5$ in order to avoid any side interaction. The mobility in last plateau does not tally with the mobility of 1:1 and 1:2 metal-methyl cysteine mixed complex. It is inferred that moiety in the last plateau is formed by the coordination of methyl cysteine anion to the metal-nitrilotriacetate moiety resulting in the formation of 1:1:1 metalNTA-methyl cysteine mixed complex as follows

$$
[\mathrm{M}-\mathrm{NTA}]+\left[\mathrm{L}^{-}\right] \quad \stackrel{\mathrm{K}_{4}}{\leftrightarrows} \quad[\mathrm{M}-\mathrm{NTA}-\mathrm{L}]^{-}
$$

The transformation of a simple complex into a mixed complex take place, hence the overall mobility is given by

$$
\mathrm{U}=\mathrm{u}_{\mathrm{o}} \mathrm{f}_{[\mathrm{M}-\mathrm{NTA}]}+\mathrm{u}_{1} \mathrm{f}_{[\mathrm{M}-\mathrm{NTA}-\mathrm{L}]}
$$

where, $u_{o}, u_{1}$ and $f_{[M-N T A]}, f_{[M-N T A-L]}$ are the mobilities and mole fractions of the [M-NTA] and [M-NTA-L] complexes, respectively. form

By adding values of the mole fractions equation (8) can be transformed into following useful

$$
\mathrm{U}=\frac{\mathrm{u}_{\mathrm{o}}+\mathrm{u}_{1} \mathrm{~K}_{4}\left[\mathrm{H}_{2} \mathrm{C}\left(\mathrm{SCH}_{3}\right) \mathrm{CH}\left(\mathrm{NH}_{2}\right) \mathrm{COO}^{-}\right]}{1+\mathrm{K}_{4}\left[\mathrm{H}_{2} \mathrm{C}\left(\mathrm{SCH}_{3}\right) \mathrm{CH}\left(\mathrm{NH}_{2}\right) \mathrm{COO}^{-}\right]}
$$

The concentration of methyl cysteine anion at $\mathrm{pH} 8.5$ is calculated with the help of equation (9). The mixed stability constants $\mathrm{K}_{4}$ is equal to $1 /\left[\mathrm{H}_{2} \mathrm{C}\left(\mathrm{SCH}_{3}\right) \mathrm{CH}\left(\mathrm{NH}_{2}\right) \mathrm{COO}^{-}\right]$and the values of $\mathrm{K}_{4}$ obtained are given in Table 1 .

The logarithm of formation constants $\left(\log \mathrm{K}_{\mathrm{ML}-\mathrm{NTA}}^{\mathrm{ML}}\right)$ for the interaction

$$
\mathrm{ML}+\mathrm{NTA} \quad \leftrightarrows \quad \mathrm{ML}-\mathrm{NTA}
$$

can be computed by relation

$$
\begin{aligned}
\log \mathrm{K}_{\mathrm{ML}-\mathrm{NTA}}^{\mathrm{ML}} & =\log \beta_{\mathrm{M}-\mathrm{NTA}-\mathrm{L}}-\log \mathrm{K}_{1 \mathrm{ML}}^{\mathrm{M}} \\
\log \beta_{\mathrm{M}-\mathrm{NTA}-\mathrm{L}} & =\log \mathrm{K}_{3 \mathrm{M}-\mathrm{NTA}}+\log \mathrm{K}_{4 \mathrm{M}-\mathrm{MTA} \text {-N }}
\end{aligned}
$$

The values of $\log \mathrm{K}_{\text {ML-NTA }}$ are found to be $8.92 \pm 0.08$ and $9.05 \pm 0.14$ for $\mathrm{Fe}$ (III) and $\mathrm{Cr}$ (III) complexes, respectively. This shows that NTA does have strong affinity to metal ions in comparison to methyl cysteine.

The precision of the method is limited to that of paper electrophoresis. However, uncertainty in the result is $\pm 5 \%$. No doubt it cannot replace the most reliable methods even though it is new approach worth developing. 


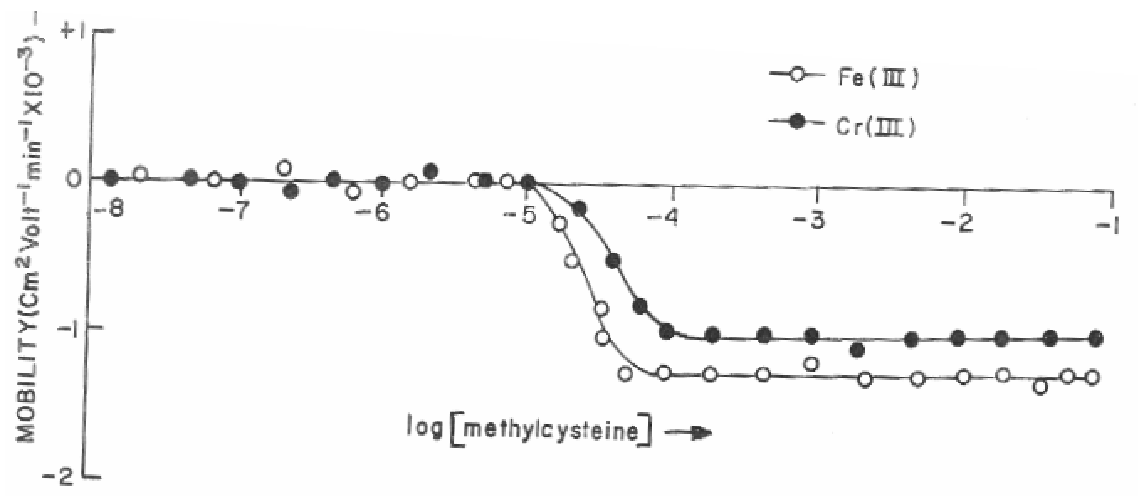

Figure 3. Mobility curves for the metal-NTA-methyl cysteine systems. Concentration of NTA = $1.0 \times 10^{-3} \mathrm{M}$. Concentration of $\mathrm{Fe}(\mathrm{III})$ and $\mathrm{Cr}(\mathrm{III})=5.0 \times 10^{-3} \mathrm{M}$. pH 8.5 was maintained by $\mathrm{NaOH}$ solution.

\section{CONCLUSION}

The simple electrophoretic technique has thus proved to be useful in deciding whether a complex system is formed or not, and if it is formed its stability constants can also be determined. It may be concluded from these studies that iron(III) and chromium(III) metal ions are essential and beneficial for biological systems but as such they are toxic. The methyl cysteine and nitrilotriacetate may be used to reduce the levels of these metal ions in living cells.

\section{REFERENCES}

1. Jokl, V. J. Chromatogr. 1964, 14, 71.

2. Biernat, J. Rocz. Chem. 1964, 38, 343 .

3. Benerjea, D. Everyman's Science 1995, 29, 176.

4. Bailar, J.C.; Emeleus, H.J.; Nyholm, R.; Trotman-Dickenson, A.F. Comprehensive Inorganic Chemistry, Vol. 3, Pergamon Press: Oxford; 1973; p 986.

5. Mertz, W. Science 1981, 213, 1332.

6. Irgolic, K.J.; Martell, A.E. Environmental Inorganic Chemistry, VCH Publishers Inc.: Florida; 1985; p 256.

7. Perrett, D.; Snedden, W.; Stephena, D.A. Biochem. Pharmacol. 1976, 25, 259.

8. Angove, H.C.; Yoo, S.J.; Munck, F.; Burgess, B.K. J. Biol. Chem. 1998, 273, 26330.

9. Benzie, I.F.F.; Szeto, Y.T. J. Agric. Food Chem. 1999, 47, 633.

10. Maranger, R.; Bird, D.F.; Prince, N.M. Nature 1998, 396, 248.

11. Watson, A.J. Nature 1997, 285, 587; 1994, 371, 143.

12. Lovely, D.R.; Woodward, J.C.; Chapel, F.H. Nature 1994, 370, 128.

13. Widdel, F.; Schnell, S.; Heising, S.; Ehrenveich, A.; Assumus, B.; Schink, B. Nature 1993, $362,834$. 
Brij Bhushan Tewari

14. Groyer, R.A. Toxicology: The Basic Science of Poisons, Klaassen, C.D.; Amdur, M.O.; Doull, J. (Eds.); Macmillan Publishing Company: New York; 1986; p 596.

15. Kaim, W.; Schwedrski, B. Bioinorganic Chemistry, John Willey: Chichester, England: 1994; p 151.

16. World Health Organization Trace Elements in Human Nutrition and Health, World Health Organization: Geneva; 1996, pp. 155, 259.

17. Sehwarz, K.; Mertz, W. Arch. Biochem. Biophys. 1957, 72, 515.

18. Douglas, T.; Dickson, D.P.E.; Betteridge, S.; Charnock, J.; Garnes, C.D.; Mann, S. Science 1995, 269, 54.

19. Whitfield, J.B.; Zhu, G.; Heath, A.C.; Powell, L.W.; Martin, N.G. Alcohol Clin. Exp. Res. 2001, 25, 1037.

20. Sekowska, A.; Kung, H.-F.; Danchin, A. J. Mol. Microbiol. Biotechnol. 2000, 2, 145.

21. Cefalu, J.W.T.; Wang, Z.Q.; Zhang, X.H.; Baldor, L.C.; Russell, J.C. J. Nutr. 2002, 132, 1107.

22. Morris, B.W.; Kouta, S.; Robinson, R.; MacNeil, S.; Heller, S. Diabet. Med. 2000, 17, 689.

23. Ghosh, D.; Bhattacharya, B.; Mukherjee, B.; Manna, B.; Sinha, M.; Chowdhury, J.; Chowdhury, S. J. Nutr. Biochem. 2002, 13, 690.

24. Simon, F.-G.; Meggyes, T. Land Contam. Reclam. 2000, 8, 103.

25. Commission of the European Communities Report of the EC, Scientific Committee for food, Commission of the European Communities (CEC): Luxembourg; 1993, Series 31.

26. Liu, Z.D.; Hider, R.C. Coord. Chem. Rev. 2002, 232, 151.

27. McDonald, H.J. Ionography, Electrophoresis in Stabilized Media, Year Book Publications: Chicago; 1955.

28. Shaw, D.J. Electrophoresis, Academic Press: London; 1969.

29. Tewari, B.B.; Singh, R.K.P.; Kumar, V.; Yadava, K.L. J. Chromatogr. 1991, 547, 554.

30. Tewari, B.B.; Singh, A.K.; Kumar, V.; Yadava, K.L. Proc. Nat. Acad. Sci. (India) 1991, 61, 13.

31. Tewari, B.B.; Singh, R.K.P.; Yadava, K.L. J. Chromatogr. 1991, 542, 537.

32. Tewari, B.B.; Singh, R.K.P.; Chander, R.; Yadava, K.L. J. Natn. Sci. Coun. (Sri Lanka) 1993, 21, 73.

33. Blackburn, J.R.; Jones, M.M. J. Inorg. Nucl. Chem. 1973, 35, 1605.

34. Perrin, D.D. Stability Constants of Metal Ion Complexes, Part B, Organic Ligand (IUPAC Chemical Series, No. 22), Pergamon Press: Oxford; 1979.

35. Martell, A.E.; Smith, R.M. Critical Stability Constants, Vol. 1 (Amino Acids), Plenum Press: New York; 1974.

36. Elenkova, N.G.; Tesoneva, R.A. J. Inorg. Nucl. Chem. 1973, 35, 841.

37. Rabenstein, D.L.; Elakney, G. Inorg. Chem. 1973, 12, 128. 